\title{
THE FRENCH MEDICAL PROFESSION'S PERCEPTION OF ITS SOCIAL FUNCTION BETWEEN 1776 AND 1830
}

by

\author{
TERENCE D. MURPHY*
}

INTRODUCTION

UNDER THE Ancien Régime, only the Hippocratic oath bound together French medical practitioners. Beyond the commitment to heal the sick and to conserve the healthy, medical men had little in common. They were a highly stratified group differing in social origins, education, and clientele. In the $1770 \mathrm{~s}$, the imperatives of political reform initiated a debate on the nature of medical practice and prompted royal administrators to ally with leading physicians and surgeons in an attempt to organize the medical arts. The Société Royale de Médecine de Paris, founded in 1776, provided an institutional setting within which this objective could be pursued. Subsequently, the French Revolution provided further incentive to re-evaluate medicine's vocation in a society undergoing profound modifications of its legal and social conventions. During the ensuing decades, the weight of foreign wars and the burden of early industrialism posed another set of problems which prompted physicians to re-examine traditional medical practices and to formulate new arguments which would justify a special place for the medical profession in French society. The purpose of this essay is to study these developments through an analysis of the methods and rationale of medical intervention in national life between 1776 and 1830. ${ }^{1}$

THE SOCIÉTÉ ROYALE DE MÉDECINE DE PARIS: THE POLITICS OF HEALTH AND CULTURE

During the Ancien Régime disease and poverty ravaged urban and rural communities, exhausting local institutions designated by custom to aid the sick and the needy. Publicists, exemplified by the physiocrats' leader Quesnay, repeatedly called attention to institutional failures, pointing out that private charity, philanthropic foundations, and religious orders could not resolve the pressing problems of the sick and unemployed. Nor were they the ideal channels for so doing. Public order required society's engagement in the poor's plight, and not merely an individual's contribution.

*Terence D. Murphy, Ph.D., The American College in Paris, 31 Avenue Bosquet, 75007 Paris, France.

${ }^{1}$ George Rosen criticized a preliminary draft of this essay. Only Professor Rosen's untimely death deprived the author of further suggestions. The bibliography on the French medical profession and social medicine is already extensive. The most thorough bibliography is found in Jacques Léonard, 'Les médecins de l'ouest au XIXe siècle', (doctoral dissertation, University of Paris, 1975). I am grateful to M. Léonard for having oriented my first efforts in this area, and to M. Jean-Pierre Peter for his helpful advice. Currently, Ann Fowler La Berger, Bernard Lecuyer, Jean-Pierre Goubert, and Jean-Pierre Peter are working in this area examining documents from local health boards as well as records of medical associations and their journals or periodicals. 


\section{Terence D. Murphy}

In the 1770s the king's ministers and influential physicians took the first steps to improve medical services. The most promising of these moves was the establishment of the Société Royale de Médecine whose aim was the co-ordination of efforts to shield the population and livestock from disease. This company enjoyed royal subsidies and the backing of the reputable Académie des Sciences. In addition, it was armed with an official publication which not only treated epidemiological questions, but also tried to set down new guidelines for French medicine.

The popularity of the new society and especially the king's generous endowment angered the Faculté de Médecine de Paris, traditional custodian of medical knowledge and jealous guardian of acquired privileges. ${ }^{2}$ The Faculté quickly established a committee on epidemics, affirming that its own interest in public hygiene made the new society unnecessary. Here as elsewhere an empty claim often measures the perceived importance of the pretended virtue. Having neglected an obvious need, the Faculté had only contributed to its isolation and its image of social irrelevance. The public's health and its conservation rarely troubled the Faculté, whose attention was fixed on the individual patient and on the identification and classification of illnesses and not on the problem of the social context effecting them. The new Sociéte confronted this problem and widened the domain of medical intervention, shifting its focus from therapeutics to conservation, from the individual to the public.

In this combat the leaders of the Sociéte Royale portrayed their opponents as the defenders of scholastic obscurantism and narrow self-interest. The reformers, on the contrary, appeared as the advocates of scientific objectivity and civic virtue. As such they solicited aid from the empirical sciences to improve the medical arts and to further the public good. Specifically, the call for precise observation of pathologies brought medical instruction into hospital, initiating a movement often referred to as clinical medicine. ${ }^{3}$ Toby Gelfand's unpublished thesis on French eighteenth-century surgery clearly illustrates this achievement. Eventually, the profession's pedagogical objectives required revision of hospital administration, public financing, and patient care. These developments, as Michel Foucault's essay demonstrates, enhanced medical education and reformed a neglected institution.4

While deeply committed to such reforms, the Société Royale focused much of its attention on rural France, a population far beyond the controlled environment of laboratory and clinic. In the absence of a suitable medical network, this larger segment of the nation often went unserved. To fill this need, the Société Royale sought to unite provincial practitioners to Paris, the administrative and scientific centre of the kingdom. Frequently working in isolation from others, the rural physicians responded favourably to this overture. For once they received formal recognition and warm encouragement from the authorities. If this support did not always reinforce their position in the local community, at least it announced the practitioners to an enlightened corporate body pursuing the noble cause of health care.

With a channel opened to the centre of science and its culture, they could pursue

2 Paul Delaunay, Le monde médical parisien au XVIIIe siecle, Paris, J. Rousset, 1906.

- Erwin H. Ackerknecht, Medicine at the Paris hospital, 1794-1848, Baltimore, Md., Johns Hopkins Press, 1967.

- Michel Foucault, Naissance de la clinique, Paris, Presses Universitaires de France, 1963. 


\section{French medical profession's perception of its social function, 1776-1830}

their combat against the vendors of secret remedies who profited from popular credulity. These doctors, posing as the interpreters of rational science in the countryside, criticized folk beliefs, curtly dismissed by the missionaries of urban civilization as the product of crass ignorance. "Soigner, c'est diriger", a motto appropriate to the Enlightenment's crusade against superstition in all forms, was well suited to these men and their task. ${ }^{5}$

As part of their work the rural physicians gathered information on temperature, rainfall, and patterns of recurrent sicknesses. Once forwarded to Paris, these data provided the raw material for the construction of a medical topography, a study capable of indicating noxious environmental conditions conducive to epidemics or endemics. Guided by such information, physicians could recommend preventive measures destined to safeguard the population from disorders generated by natural conditions or by social life. These rudimentary epidemiological studies satisfied the administrator's need for information on the factors contributing to the state's power. As such they were early attempts to put medical knowledge at the service of the state.

During the same period, members of the scientific community urged the collection of such data for a larger purpose. Following Bacon's call, social observers tried to draw up a natural history of man. Condorcet, the founder of social mathematics, encouraged the realization of this programme by devising his decimal system of classification for the organization and retrieval of information. Related to the Baconian ambition and its partial realization in Condorcet's social mathematics, the efforts of the Société Royale echoed and amplified a theme of the scientific revolution: the elaboration of a science of man through objective analysis of his social and natural characteristics. Later, in the first quarter of the nineteenth century, a more elaborate medical topography would serve as the basis of a public health movement, another more complex response to an obvious socio-political problem.

With the establishment of the Société Royale, the grid of medical care reached out to touch more aspects of public life, justifying the profession's claim to recognition for service. In his study of the Société Royale Daniel Roche has analysed this connexion between the claim for social place and the efforts of the médecine des épidémies. Situating this action in the context of pre-Revolution France, Roche has noted the proclaimed reverence for an egalitarian spirit which respected talent before birth and which placed public services before corporate or personal interest. ${ }^{6}$ This rhetorical stance projected the Société as a model institution for a reformed society. If an egalitarian spirit reigned within the republic of scientific medicine, its membership laboured to identify the characteristics of competent medical practice and persistently decried the pretensions of outsiders. In this way the reformers imitated the more traditional members of the Faculté, for they too wanted to restrict legitimate medical practice to trained professionals.

The innovation of the Société Royale rested elsewhere. Its most distinguishing feature was an interest in collective endeavours and administrative reforms which would give France a national health policy supervised by competent medical authori-

\footnotetext{
${ }^{8}$ Daniel Roche, 'Talents, raison et sacrifice: l'image du médecin des lumières d'après les éloges de la Société Royale de Médecine, 1776-1789', Annls Eco. Soc. Civ., 1977, 5 : 881.

- Ibid., p. 882.
} 


\section{Terence D. Murphy}

ties working in close collaboration with ministers of the state. In these efforts they foreshadowed later appeals for an enlarged public responsibility for the medical corps, but in 1789 their corporate identity defined an area of legal privilege which liberal doctrine could not permit. Passion for the public good did not suffice in an era demanding structural changes which would eliminate the clusters of academies and societies criticized by many as havens of élitism and symbols of ministerial despotism.

THE FRENCH REVOLUTION: VICQ D'AZYR'S RESPONSE TO THE DEMOCRATIZATION OF MEDICAL PRACTICE

With the coming of the French Revolution, sweeping measures eventually threw out the patchwork of inefficient and inadequate poor relief programmes inherited from the Ancien Régime. Notable for its dilapidated condition and abominable service was the Parisian Hôtel-Dieu. For many years it had been singled out for renovation by investigating committees and special commissions, but these had failed to bring reform to the institution. In their turn, the Cahiers de doléances expressed a similar dissatisfaction. Only when the abolition of feudal rights wiped out the main financial support for this establishment did the administration resign. In March 1791, Pastoret, procureur-général-syndic, named Cabanis to the governing board. He took this move to express his appreciation for Cabanis's sensitive and incisive articles on health care reform and the medical profession's role in bringing about such change.

At the national level, the new leadership manifested a commitment to bettering the lot of the poor. But before moving in this direction, the Constituent Assembly and afterwards the National Assembly had to confront the disruption of the economy caused by the currents of revolution. Unfortunately, emergency measures, never a substitute for systematic reform, continued the ad hoc committees and subsequent Lettres patentes so common during the Ancien Régime. Like the credit system, poor relief and hospital reform suffered from the lack of national institutions required for the execution of policy.

The ideas, the noble sentiment, and on occasion the political will were available but not the institutional framework. Much like France itself, the health system lacked a constitution or an ordering mechanism for the execution of decisions. Only fundamental reforms could meet current needs.

In 1790, Vicq d'Azyr proposed such measures in his Nouveau plan de constitution pour la médecine en France, presented to the National Assembly in the name of the Société Royale de Médecine. The plan put the medical profession under the protection of the state, a policy that would continue the special privileges of the Sociéte and extend its control to all aspects of medical practice. Under the patronage of the state, the medical profession would foster national goals through its network of influence in rural communities. Funds provided by the government would pay the salaries of the rural doctors, the emissaries of the National Assembly. Ideally, these men would bring the science of the centre to the outskirts of civilization, connecting the rural poor and ignorant with the talents and wisdom of urban life. Constructed after Turgot's model of municipal government reform, Vicq d'Azyr's health system 
had a centre and the administrative support required to disseminate information. Paris doctors, of course, would be the ideological masters of his arrangement, a suggestion that failed to excite the Girondist group listening to his proposal. Transformed and enhanced, the Société would become this natural centre, a new academy fostering medical learning and public hygiene at every level.

Another suggested change that indicates the political tenor of the times concerned the control over patented medicines. Previously, the Sociéte had taken charge of this sensitive matter, but now it conceded authority to the deputies. In fourteen years, the Société had approved only four new drugs. This careful supervision of the drug market had been marked by a lack of concern for the economic advantages of inventors, manufacturers, and merchants. During his tenure Vicq d'Azyr had opposed the multiplication of patents, comparing them to a form of occultism which kept needed remedies in the hands of a few. The assembly could better serve the public if in the future "it refused to grant a patent which would keep a useful remedy secret". Going further, he suggested that the nation should purchase every new remedy superior to related medicines and put it immediately at the disposal of the public. ${ }^{7}$ Despite these recommendations which reiterated former policy, he conceded to economic liberalism by placing the licensing power in the Assembly, the protector of individual and public interest: "It is not for us, but for the legislators of France to examine what right an individual has to property whose alienation touches the health of all and to what point one ought to sacrifice particular interest to the public good". ${ }^{8}$

While certain of these suggestions corresponded to contemporary feeling, Vicq d'Azyr's appeal for a special role for the Société Royale ran against the current of public opinion. Numerous critics attacked the Société and other institutions which had enjoyed special privileges under the Ancien Régime. While defending his institution, Vicq d'Azyr openly acknowledged the conflicts that had marred the history of his profession and decried the esprit de corps which isolated groups from the common cause. He argued, naturally enough, that the Société was an exception. ${ }^{\ominus}$ Far from abolishing the Société, he urged its transformation into an academy charged with the supervision of medical reform. In response to this petition, Retz, a drug manufacturer frustrated by the Sociéte, was only one of those who spoke against the continued existence of "this ministerial society", 10 a potent phrase clearly identifying the organization with its protectors who now were made to bear the burden of every misfortune striking the realm.

In 1791, the decree was issued which abolished the corporations including the Société. Into the void came the quacks and vendors of secret remedies only too glad to ply their trade or market their wares without the overlords of established medicine condemning their practice. But if the charlatans increased in number, trained physicians were lacking. Six hundred members of the profession had been killed in the first eighteen months of the nation's wars and adequate replacements were

\footnotetext{
7 Félix Vicq d'Azyr, Nouveau plan de constitution pour la médecine en France, Paris, Imprimerie royale, 1790 , p. 128.

Ibid., p. 129.

Ibid., p. 8.

${ }^{10}$ [-] Retz, Exposé succinct à l'assemblée nationale sur les facultés et les sociétes de médecine, Paris, Imprimerie royale, 1790, p. 6.
} 


\section{Terence D. Murphy}

desperately needed. By passing the law of 14 Frimaire Year III (14 December 1794), the Assembly met this need. The new legislation provided for the opening of the Ecoles de santé, medical schools especially designed for contemporary needs. Modelled on the Ecole Centrale, the school for military engineers, the Ecoles de santé took over the role of the former medical faculties, judged hopelessly inadequate by Fourcroy, the initiator of this reorganization. Repeating suggestions put forth by Vicq d'Azyr, Fourcroy stressed that "little reading, but a lot of observation and practice would be the base of the new teaching". Under the rubrics of these reforms, public health, "which included all the sciences of man", would finally have its proper place in medical education. ${ }^{11}$ In the spirit of democratic France of 1793, these schools were open to the public; nevertheless, the students followed a strict schedule similar to that of the Ecole Centrale. They also received an equivalent scholarship permitting them to complete their three-year programme without the aid of family funds. It was an open system, democratic in inspiration, utilitarian in purpose. Ultimately, the schools served a nation at war; and, requiring hospital experience, they prepared the way for clinical medicine. ${ }^{12}$

MEDICINE'S SCIENTIFIC REVOLUTION: CLINICAL MEDICINE, BICHAT, AND PUBLIC ESTEEM

Clinical medicine described more than an approach to medical learning; it depicted a new attitude towards medical practice which stressed detailed observation of the sick, scrupulous attention to case histories, and comparative analysis of those suffering from the same ailment. The hospital, the forum for this new orientation, now attracted the doctor much more than when medical science was relegated primarily, if not wholly, to commentaries on texts or anatomy lessons. ${ }^{18}$ Even those who resisted the fall of the Faculties accepted this improvement. Some, like Pariset, said that this change in medical practice supported claims that medical theory rested on observation. Others, more interested in satisfying wealthy patients, saw hospitals as experimental theatres or medical laboratories wherein remedies could be tested on the poor, the only clients of such institutions. ${ }^{14}$ Those who could afford to avoid the perils awaiting, such as the day labourer, the apprentice, or the homeless, called for the doctor better prepared for having treated similar cases at hospital. ${ }^{15}$ There techniques could be perfected, rendering medical intervention more efficacious, strengthening the doctor's position. In a word, efforts to systematize, categorize, objectify the study of disease in the neutral framework of the hospital were encouraged within a culture sustained by the belief that scientific and technical knowledge translated quickly into material advantage.

Despite these gains, certain physicians objected to a worrisome consequence of

11 Antoine-François Comte de Fourcroy, Rapport à la convention au nom des comités de salut public et d'instruction publique, 7 frimaire an III, p. 6. Quoted in Foucault, op. cit., note 4 above, p. 70.

12 An excellent discussion of the French medical profession during the wars is found in Diana B. Weiner, 'French doctors face war, 1792-1815', in Charles K. Warner (editor), From the ancien régime to the popular front, New York, Columbia University Press, 1969.

13 Foucault, op. cit., note 4 above, pp. 63-86.

14 For a discussion of the social composition of the clients of these institutions see Arthur E. Imhof, 'The hospital in the 18th century: for whom?', J. soc. Hist., 1977, 10: 448-470.

16 Foucault, op. cit., note 4 above, p. 84. 
these measures: the subordination of the profession to public authorities. The major obstacle impeding progress towards greater independence was the widespread popular belief that the medical profession repeatedly faltered before problems it could not resolve. In this context, the strategy for social advance was easy to conceive. Only by revolutionizing medical science could the medical profession lay claim to specialized knowledge. With this pre-eminence established, they could reassert an authority that had been struck down by the laws of the Revolution. Not only would the charlatans be swept aside, but state administrators and in particular military authorities would have less justification for interfering in the organization of medical services.

The formation of new medical societies marked the medical profession's first step towards greater control over the administration of hospitals, medical education, and local health care. The Société de Santé was the first among the new societies. Founded on 22 March 1796, the ostensible purpose of the new Sociéte was the publication of the remaining memoirs of the defunct Société Royale de Médecine and those of the Académie Royale de Chirurgie. It would also bring out medical research performed by its members and re-establish contact with the international medical community through correspondence with foreign academies. More important for the profession, however, was the end to thecentury-long feud that had divided physicians from surgeons. Traditional rivals now joined hands to save the medical hierarchy as much as to rescue medicine from the democratic spirit of 1793 . Political as well as medical reasons dictated this switch. Weak in their separate camps and ill-defended against the state's attacks on organized medicine, these former opponents recognized that a united front and an active surveillance of their interest could raise the low social standing accorded to the medical profession and at the same time render a service to medical science by bringing together the branches of the tree of medicine.

The incorporation of the word santé into the name of the new society indicated that the Parisian medical profession had not yet escaped from the limits imposed by a government seeking to protect the liberal principle of freedom of choice in health services much more than the position of the profession. Sabatier, the secretarygeneral of the Société de Santé, reflecting on the name of the new organization declared that santé was the word linked closely to the political movements of the early revolution, a time of anarchy disruptive of learning and detrimental to the reputation enjoyed by French science. ${ }^{16} \mathrm{He}$ must have been more at ease when in December of 1796 the appellation santé was dropped and the new group became known as the Société de Médecine. The implications of this change were clear enough. The profession was organizing to assert more forcefully its claim to the monopoly of health care.

Excluded from this new group, composed primarily of the older members of the former Faculté, were Bichat, Alibert, and other younger members of the profession. Upon their insistence, the President of the Ecole de Santé agreed to provide space for the beginning of the Société Médicale d'Emulation, founded in 1796. Aside from age and perhaps prestige, no ostensible difference marked off the two new families. In fact, Sabatier's group opened their doors to Bichat in 1797, testifying to their

16 J. C. Sabatier, Recueil périodique de la Société de Santé (de médecine) de Paris, 16 vols., 17961802, vol. 2, pp. 234-235. 


\section{Terence D. Murphy}

esteem for his medical research in pathological anatomy. Alibert, unlike Bichat, perceived a social role for the medical profession. Councillors of the state, they had to assume the lead in recommending improvements in public health. In a real sense Alibert, more than Bichat, saw the new Société continuing the work of the Société Royale de Médecine. ${ }^{17}$ In fact, in 1800 when Louis Napoléon, then Minister of the Interior, asked that a medical topography of France be carried out completing the work begun under Vicq d'Azyr and Lassone, Bichat wrote to his father that his research did not permit for such time-consuming distractions. ${ }^{18}$

Bichat sought the same unity that Sabatier referred to, but he refused to accept the mere repetition of past practice as the basis for future action. Instead of praising the achievement of previous generations, Bichat boldly looked to a renewal of medicine through a re-definition of its essential problems and the organization of a science founded on unique principles. A passion for anatomical study animated Bichat and directed him away from the methods of natural history, guiding the descriptions and classifications of nosology. In Bichat's view this approach to medical science proved too limited, restricting its scope and subordinating medicine to a division of zoology. Without a reconsideration of its main problems, methodology, and formal language of description, medical science would remain a subordinate science. This continued submission would only impede progress in the therapeutic arts.

In 1799, Bichat's work on the membranes, the keystone to the new science, appeared in the Mémoires de la Société Médicale d'Emulation. François Jacob has discussed the importance of this work in the context of the debate over the nature of the ultimate components of living beings. ${ }^{19}$ In the eighteenth century, Buffon, among others, had argued for the ultimate reduction of the elements of the living world to mechanical explanation. Bichat refused this imposition which suggested that only the form of the particles distinguished the organic from the inorganic. For Bichat the existence of membranes required savants to differentiate purely chemical structures from living organization. Further proof for this position was at hand. If the building blocks existed for chemistry, organic beings, too, were composed of different tissues, each specific kind designating a particular physiological system which functioned in harmony with the total organism. Here Bichat dismissed mechanical reductionism and escaped the influence of a re-invigorated vitalist philosophy which argued that all matter, even minerals, was fundamentally organic.

Maintaining a strict distinction between the organic and inorganic worlds, Bichat argued that the nature of living matter, always subject to variation, could in no way compare to the uniformity witnessed in the movement of inorganic matter. For this reason we cannot apply the methodology of the physical sciences in the study of living phenomena. Developing his point, Bichat insisted that "the science of organized bodies should be treated in a completely different manner from those sciences having

\footnotetext{
17 Jean-Louis Alibert, 'Introduction', Mémoires de la société médicale d'émulation, 9 vols., 17971826, vol. 2, pp. xciv-xcvii.

${ }^{18}$ Pierre Huard, Sciences, médecine, pharmacie de la Révolution à l'Empire, 1789-1815, Paris, R. Dacosta, 1970, p. 222.

10 François Jacob, La logique du vivant, Paris, Gallimard, 1970, pp. 126-129.
} 
French medical profession's perception of its social function, 1776-1830

inorganic bodies as their object." 20 To complete the argument, he urged the creation of a new language saying that the vocabulary of the physical sciences, used in physiology, only leads to a confusion: force and movement, for example, have totally different meanings from one science to another.

The plan for a specially medical or biological vocabularly was never carried out, for Bichat died too young to advance his project beyond this brief theoretical outline. Previously Pinel, his friend and colleague, had proposed a coherent nomenclature for pathology, organized on the visible signs of particular illnesses, but he had never considered the anatomical and physiological questions that Bichat, the surgeon, considered to be pre-eminently important. Their colleagues, seeking new paths and dimensions for medicine, saw in Pinel's sympthologie the culmination of the development of empirical medicine which heeded the Enlightenment's demand for a science of well-ordered facts expressed in a well-defined language. But Bichat opened a new frontier. Like Cuvier's studies in comparative anatomy, he focused attention on physiological processes, requiring that pathologists pay heed to internal manifestations of disorders and not concentrate only on classifying the visible, surface signs of illnesses. ${ }^{21}$

This claim for a science of living beings had an impact on the many doctors who recognized in Bichat a representative of Baconian science as well as a master of an inspiring philosophy that rested on the unique organic quality of living beings. They supported Bichat's interpretation all the more because they believed that a science of living beings had need of a highly trained group of men who could interpret and judge its various transformations. Doctors, then, fully realized and acknowledged the link between improved social position and a revolution in the medical sciences. Far from ignoring the reciprocal effect that professional success had on social and political eminence, they repeatedly testified to this fundamental reality. Put differently, the profession's more articulate spokesmen were aware that objectives clearly stated and attained assured the group's social promotion. Unfocused efforts led to ambiguity of purpose, at least in the public mind, demanding recourse to rhetorical talents if a group were to win the social position it claimed.

The overwhelming problem of the medical profession was precisely here. Where should medical science focus its attention? Preventive health measures spared soldiers and promised improved conditions for city dwellers. But the growing demand for a science of medicine independent in principle and demonstration from the physical or natural sciences promised prestige and praise for the innovator. At least this was the view of the medical faculties, the profession's recognized leaders. In control of renovated institutions and a number of medical journals they encouraged initiatives in nosology, physiology, and anatomical pathology, and gave laurels to those like Bichat for their discoveries or clear statement of theory. In practice, this emphasis on medicine's scientific vocation justified the profession's claim to supervise the training and licensing of health officers, doctors, and other medical practitioners.

20 Marie François Xavier Bichat, Recherches physiologiques sur la vie et la mort, ed. by J. Ménétrier, Paris, Marabout Université, 1973, p. 63.

${ }^{21}$ Michel Foucault, Les mots et les choses, Paris, Presses Universitaires de France, 1968, pp. 275-292. 


\section{Terence D. Murphy}

The revolutionary authorities, however, rejected such pretensions and continued to oversee medical practice. Evidence of this frustration was the law of 19 ventôse Year XI (1803) which formally recognized the right of the officier de sante to practise on civilian clients. Long opposed to the rapid and cursory training of men destined for army and naval medical units, doctors were outraged at the passage of this law, which required only three years' previous experience as evidence of a practitioner's qualifications. Furthermore, it was the sub-prefect and not the medical commission which would examine and evaluate claims for such authorization. These measures, they argued, allowed for numerous abuses which doctors roundly condemned in their campaign for higher standards and a restricted membership in the profession.

FRANÇOIS FODÉRÉ: AN ADVOCATE OF MEDICAL ANTHROPOLOGY

By 1800 , the rational and analytic spirit of science had begun to permeate medical education, now supposedly based on the observation, identification, and classification of pathologies. This process of abstraction naturally isolated symptoms from any specific socio-cultural environment and allowed the physician to diagnose the illness against a universal norm. The procedure led to the selection of a suitable therapy which corresponded to the illness. Confident in these procedures, doctors reiterated their claim to greater responsibility for the nation's medical services. Yet it is safe to say that the contrast between the profession's pretensions and its social credibility had never been as striking. The Napoleonic era would only confirm the failure of the medical faculties to extend their limited sphere of influence and to convert a suspicious population to a new concept of health.

Although scientific medicine may also use social norms to define a disease, in general specific physical symptoms are the prime indicators of a pathological condition. Should the doctor detect a particular configuration of symptoms, he asserts with relative certitude the presence of a specific disease. In the absence of these visible signs, the doctor must hesitate and reserve judgement until more conclusive testing provides the information necessary for accurate diagnosis. Before this modern or scientific view took hold of the public mind, a quite different understanding of sickness and disease influenced attitudes towards the medical act. There was, in effect, a social grid through which people perceived illness or health. In eighteenth-century France folk beliefs of a Christian and rural culture provided men and women with an explanation of suffering and frequently suggested both the cause and remedy for particular ailments. These beliefs guided a large proportion of the population and often conflicted with the analytical procedures of modern medical practice. They certainly perpetuated an attitude of wonder and fear before sickness and death, conditions overlaid with mystery and the supernatural. ${ }^{22}$

Repeatedly, the Church explained sickness either as God's just anger punishing sin or as his beneficent warning of impending death. Believing the priest's argument or translating it into the language of folklore, the peasant could also see the devil's work,

${ }^{22}$ François Lebrun, Les hommes et la mort en Anjou aux XVIIe et XVIIIe siecles, Paris, Mouton, 1971. Popular attitudes towards death receive their best treatment in this work. A more general work is Philippe Ariès, Western attitudes toward death from the middle ages to the present, Baltimore, Md., Johns Hopkins Press, 1974. 
transmitted by a sorcerer, causing prolonged illness or sudden death. Remedies suited to the disorder were near at hand. In serious cases, the first duty of the doctor was to call the priest, who administered extreme unction which healed the troubled soul, the real subject of concern. The Latin phrases, the anointing with oil, carried a healing power communicated to the sick and felt by relatives and friends standing by. The ritual of passage gave order and meaning to tragedy, calmed fears, and encouraged others to continue daily routines. Imitating similar rituals, the doctor acknowledged this network of beliefs and reinforced the curative value of his treatment. In the absence of such concessions to the popular mind, the sick often looked elsewhere for help and reassurance. Demystifying medicine in the name of science, a process most evident in the eighteenth century, actually weakened the power of the medical profession.

François Fodéré, a most astute observer of this reversal, lamented the attention given to scientific medicine, born of anatomy and physiology, and castigated the rationalist who forgot that man will always prefer his illusions to logic as long as the latter fails to cure him, and sometimes longer ${ }^{23} \mathrm{~A}$ perceptive social commentator, Fodéré noted the pathological consequences of early industrialism and, at the same time, realized that traditional usage still governed popular attitudes towards health care. With this last point in mind, he urged physicians to recognize the influence of mental attitudes which strongly affected the labouring poor's receptiveness to the medical act. In Fodére's view, it was the medical profession's restricted view of its role that limited recognition to innovators or theoreticians of rational science. If these achievements impressed colleagues and won clients, with certain notable exceptions they affected but few people. To extend their reach, he asked his colleagues to give more attention to public health needs rather than concentrate on the problem of medical research. Most important, doctors working in that area should receive recognition and honour on a par with others devoted to laboratory study. Such a request is understandable coming from a doctor who spent most of his life advocating reform in the area of public health.

As part of his critique of this excessive zeal for discovery and theory, Fodéré turned to another aspect of medical practice, the doctor-patient relationship. Without abandoning the standards of medical science set down by its orthodox interpreters, he asked for a recognition of the psychological elements at play in the medical act. Attention to the empirical method and medical tradition, while commendable in itself, was insufficient, as it often failed to win converts to the practitioner's chosen remedies. Technical achievements might merit awards from the scientific community obviously convinced of the value of such advancement. Immersed in a world whose culture approved and reinforced the pursuit of such knowledge, the medical profession represented by the newly founded societies and journals, had only disdain for those who manipulated the populace's credulity or appealed to a less enlightened rationale for their practice.

${ }^{23}$ François-Emmanuel Fodéré, Traité de médecine légale et d'hygiène publique ou de police de santé adapté aux codes de l'empire français et aux connaissances actuelles, 6 vols., Paris, impr. de Mame, 1813. Fodéré was a member of the Marseilles Board of Health, a university professor, and an expert on public health problems. During the Napoleonic wars he served as a health officer in the army. 


\section{Terence D. Murphy}

Fodéré was of another opinion. The large majority had no share in the scientist's culture, failed to understand his system of explanation, and more often than not were terrified of the heroic remedies suggested by certain doctors. Needless to say, they were also reluctant to pay fees when they found them excessively heavy. Charlatans, Fodéré argued, were adept at the theatrical arts and readily played with credulity wherever it was found, winning the confidence of the sick or those in need of reassurance. Doctors should be aware of this and should appease the popular desire for special drugs or secret remedies. The need for illusion, so evident in both town and country, could only be a moral necessity, a peculiar feature of social life where priest and magician, charlatan or doctor, came to exorcise sin or sickness, fear or uneasiness. Hence, the recommendation: "Imitate the charlatans in the way they nourish illusion, but without imitating their ignorance . ..". ${ }^{24}$ Fodéré believed this was a realistic and not a radical proposal. To those who would object, he had a ready answer: "In what profession among those which must deal with the human mind, is recourse to illusion unnecessary?" ${ }^{25}$ In this context Mesmer, infamous for abusing such an insight, came to Fodérés mind. So did images of "witches-priests-medicine men of the savages and negroes."26 Their power over the popular imagination only proved it was impossible to persuade by reason alone. Acknowledging the defeat of the Enlightenment's programme, he urged doctors to satisfy their patients' credulity by carrying out those ritual gestures that brought such popularity to Mesmer and such influence to the witch-doctor.

With this discussion Fodére was arriving at the end of his six volumes on legal medicine and public health. Here he paused to explain the disrepute into which the medical profession had fallen since the seventeenth century. Unlike the sponsors of clinical medicine, he did not point to the rival claims of the physicians and surgeons as the essential factor in the decline in prestige. Nor did he, like they, suggest a more rigorous, scientific base for medical speculation to recapture lost influence. His explanation pointed not so much to the internal obstacles blocking medical progress or holding up technical efficiency. The reason for the decline of the doctor's reputation lay with the satirist, "the first to arrogate the right to ridicule the doctors". ${ }^{27}$ Unmasking the physician, Molière's dubious achievement, left the medical practitioner without his sacerdotal guise and reduced his art to a mere trade. The popular imagination, Fodéré argued, could not accept the transformation, and the state could not afford it. "Governments should know that all is tied in the social order; that all institutions whatever they might be, should be respected by the multitude and that when contempt touches anyone of them it is the signal for the fall of them all . ..".28 Political upheaval and charlatanism are the result.

The satirist alone was not made to bear the burden of disorder. Fodéré also blamed those whose passion for precision excused no error. The furor for the so-called exact sciences was, in part, responsible for this attitude guiding the scientific com-

\footnotetext{
24 Ibid., vol. 6, p. 411.

25 Ibid.

${ }^{26}$ Ibid., vol. 6, p. 413, note 1 .

27 Ibid., vol. 6, p. 415.

28 Ibid.
} 
munity, an attitude which subjected medical practice to standards it too often failed to meet. But if he lamented a past when "medicine was more powerful than at present", ${ }^{29}$ Fodéré was only exposing a prejudice of his own, namely that the belief in progress was the most dangerous illusion of all. Having stripped the magicianpriest of his robes, the new ideology of progress exposed the doctor and his cures to a tribunal respecting only positive laws. While sufficient and necessary for the scientific community, this new faith, argued Fodéré, was not widespread. For this reason the populace continued to listen to those who allayed their fears and cared for their ills regardless of diploma. Until the medical profession could provide efficacious and reassuring treatment, this bifurcation of medical culture would persist. Medical science had need of reform, but so too did the people's mentality.

THE EVIDENCE AND RATIONALE FOR THE PUBLIC HEALTH MOVEMENT: LOUIS VILLERMÉ AND PHILIPPE BUCHEZ

In the first quarter of the nineteenth century, several perspectives on the medical profession's social function guided doctors in their suggestions for innovation. On the one hand, some physicians' technical abilities and theoretical brilliance won the support of a clientele impressed by scientific achievements. On the other hand, there were doctors, like Fodéré, who were more concerned with preventive medicine and public health than with the intricacies of anatomical pathology or technical innovation. Fodérés notion of the physician's social function was in no way based on a denigration of rational science. However, he did argue for a recognition of the impact of socio-cultural patterns on perceptions of health and an awareness of the deleterious influence of degraded physical surroundings on men.

Medical preoccupations cut two ways in this period of reconstruction. The public frequently heard proclamations of medicine's scientific revolution and witnessed the profession's growing attention to public health matters. Michel Foucault has discussed the former aspect of medical history in his illuminating analysis of Broussais's 1816 pronouncements. ${ }^{30}$ In this final section of the essay, we shall examine the evidence and rationale for the public health movement brought forth by Louis Villermé and Philippe Buchez.

At the end of the Napoleonic Wars, Louis Villermé, a former army surgeon, joined the Paris health council. From this position he united his efforts to those of ParentDuchâtelet and Pariset to advocate reforms in the area of public hygiene. In taking this step he clearly identified his work with the practices dating back to the Société Royale de Médecine, when administrators and physicians first began to publish information on national health problems. Until the founding of the society, Villermé wrote, ministers of the state guarded this information in chancellories closed to public scrutiny. With the help of the medical profession, enlightened administrators had ended this practice. To advance this process of public involvement in national concerns, Villermé encouraged the further diffusion of results gathered from scientific inquiries on hygienic conditions in factories, mines, hospitals, prisons, and army life.

20 Ibid.

${ }^{20}$ Foucault, op. cit., note 4 above. 


\section{Terence D. Murphy}

In 1817, the Prefet Chabrol commissioned a medical topography of Paris similar to those carried out by the defunct Société Royale de Médecine. Recherches statistiques sur la ville de Paris et le département de la Seine, published in 1821, was the fruit of this initiative. Villermé used these records to demonstrate what most informed people already knew, the inequality of the rich and the poor before death. In this and subsequent studies, Villermé and his allies in the public health movement pointed out the contradiction between the rhetoric and progress and the facts of social life. More specifically, their studies placed Paris, the proclaimed centre of civilization, under the neutral eye of the census and found her wanting. Despite an increase in population, a traditional sign of prosperity, serious problems troubled the city. Infant mortality was high and sanitary facilities poor, particularly in those neighbourhoods around the Hôtel de Ville. Workers in a number of trades faced serious health hazards, and the food industries, especially the marketing of meat, left much to be desired. These features prompted the comment that longevity and not merely population increase indicated the nature of a society. ${ }^{31}$ In effect the study revealed a society in conflict with its aspirations. Rather than free individuals joined together by law under recognized authority, a less flattering image appeared when seen against the background of urban decay and the conditions of industrial labour.

The municipal health council, charged with advising the police of infractions in matters of public health, made wide use of this report and other studies to alert the public of the need for change. In preparing its case for urban renewal, the council struck at the passivity of the authorities and public before persistent problems. But as the council held the illusory belief that reform could be accomplished through the structures provided by the Restoration government of Louis XVIII, their recommendations did not go as far as those of social critics outside the council who urged fundamental reforms of the economy. Fostering a laissez-faire economic doctrine and prescribing its supporting social values did not impede these men from attending to the needs of the less fortunate. They even urged administrators to consider the city as a social unit and to support legislation requiring building contractors to respect public health norms in new constructions. ${ }^{32}$

The proposed law so rudely clashed with political and economic realities that it remained far beyond the realm of the possible. Primarily a consultative body, the council had no hold on its superior, the prefet, but through its skilful presentation of statistical findings and consistent solicitude for the needy, it did stir a middle class public to admit the value of reform. Between the admission of this social need and its satisfaction there stood the inertia of administrative routine and above all the self-interest of the individual property owner. The public health movement suffered an additional handicap, the isolation of the municipal health council. Ultimately, their recommendations appeared before the Minister of the Interior, but no administrative mechanism guaranteed feedback from this official. On several occasions funds were requested for preventive action against epidemics threatening towns.

31 Recherches statistiques sur la ville de Paris et le département de la Seine, Paris, Impr. royale, 1821 , vol. 1, pp. 55-56.

'22 Conseil de salubrité rapports généraux des travaux 1829-45. See Ann Fowler La Berger, 'The Paris health council, 1802-1848', Bull. Hist. Med., 1975, 49: 339-352. 
French medical profession's perception of its social function, 1776-1830

Refusals were rare; failure to respond was commonplace.

Villermé hoped his action on the council and his detailed statistical reports would increase public awareness of social ills and ultimately put pressure on even the most reluctant to permit the execution of the necessary reforms. In his view, the medical profession should lead the way in turning specialized inquiries into public knowledge, for, in addition to the healing of the sick, the doctor had another responsibility, the development of a profound sensitivity to the problems of social organization. Taking this recommendation seriously, Villermé and his colleagues founded the Annales d'Hygiène publique et de Médecine légale, a review dedicated to informing physicians, legislators, magistrates, administrators, and the public at large of social needs. ${ }^{33} \mathrm{Here}$ the editors posed as spokesmen of a moral order which they urged their colleagues to propagate and protect. To their way of thinking, public hygiene had a mission which went beyond the reform of those institutions touching daily life; its future also lay in the amelioration of the moral order. Examining the habits of men, it could affect the progress of the human spirit by informing the moralist and legislator of the origins and effects of crimes and other social infirmities. With this task to fulfil, Villermé wrote, the doctor could not neglect any aspect of the science of man. ${ }^{34}$ He became in fact a social scientist fully responsible for inquiring into human behaviour and for informing the legislator of the best way to direct citizens towards the practice of their social responsibilities.

In Médecin de campagne Balzac portrayed the doctor who had assumed these responsibilities. A lay saint, the doctor brought the message of enlightenment to a people estranged from the centres of culture. Later the Dictionnaire de médecine took up this same theme. In the article médecine politique, written by Marc, Villermé's associate at the Annales d'Hygiène, the perceived social function of the doctor took on sharper focus. One passage is worth quoting at length: "As the vigilance of the government can only exercise its hold on the individual will in a limited number of cases, and as the anomalies, and whims of this same will are rarely within the competence of positive law, public hygiene must spread notions of hygiene to the diverse classes of the society in order to combat prejudices, errors, apathy and negligence; it must, in a word, persuade where constraint is impossible."35 This message is clear. Médecine politique and the public health movement as a whole implied not so much the defence of the labouring poor but their assimilation into a cultural network which would require a radical modification of their behaviour and a consequent emulation of the values of recognized social superiors.

Earlier, Philippe Buchez, medical doctor, republican activist, and Saint-Simonian, had given the term médecine politique a different meaning. Between 1825 and 1832 he wrote on a variety of subjects, but of special interest are his articles on health care and the medical profession. ${ }^{36}$ While he acknowledged the importance of Villermé's

\footnotetext{
2a See Bernard Lecuyer, 'Les enquêteurs sociaux de 1820 à 1850: un essai d'interrogation sur une lacune actuelle de l'histoire de la statistique et de l'histoire sociale en général', Pour une histoire de la statistique, Paris, I.N.S.E.E., 1977.

's Louis Villermé, 'Sur l'hygiène morale', Annls Hyg. publ. Méd. lég., 1830, 4: 25.

35 Charles-Chrétien-Henri Marc, 'Médecine politique', Dictionnaire de médecine, 21 vols., Paris, Bechet, 1821-1828, vol. 17, pp. 312-313.

so The most thorough treatment of Buchez is found in François-Andre Isambert, De la Charbonnerie
} 


\section{Terence D. Murphy}

statistical studies, Buchez believed they were only the first step towards the formation of a national health policy. And while he recognized the potentially beneficial effect of active health councils, he decried their present inability to bring about significant reforms. These failures, Buchez concluded, were not the result of inadequate information, but the absence of an organized group persistently working to achieve concrete results. Naturally enough, Buchez suggested that members of the medical profession become the credible sponsors of innovative reforms. To facilitate these efforts, new institutions were necessary. A national medical council, for example, could coordinate the efforts of local health boards and, more importantly, this body would serve as a tribunal for the defence of the popular classes. These measures implied a socio-political function for the profession reminiscent of that envisioned by the Société Royale. In brief, Buchez called for the establishment of a médecine politique, a term he used to identify the activities and attitudes which would associate the profession primarily with the health problems of a large and long-neglected clientele, the working poor. Beyond health services, physicians would act as the intermediaries between the poor and the various administrations, a role which would permit them to diffuse social tensions and to lead the movement for industrial reform.

A convert to Saint-Simonianism, Buchez elaborated his ideas on the medical profession within the context of his tutor's attempts to formulate the principles for a science of society. In debt to Condorcet and Bichat for his conceptual vocabularly, Saint-Simon speculated on the modalities of the social organism's future progress. It was on the basis of his teacher's misinterpretation and distortion of these precursors that Buchez put forth his own suggestions on the medical profession's place in a genuine social science. In the light of this tortuous heritage, it is worthwhile to examine the groundwork laid down by Saint-Simon.

In the early nineteenth century, the life sciences provided the metaphors for social theorists seeking to express their tenuous conclusions in a scientific vocabulary. SaintSimon, an early practitioner of this hazardous procedure, explained the origins and evolution of industrial society with terms recently developed within the medical and biological sciences. In an essay entitled De la physiologie appliquée d l'amélioration des institutions sociales, he argued that the principles of physiology were valid for all the human sciences: "It permits us to know those economic factors which are contrary to our health, well-being, needs or desires and those which necessarily increase the extension of our means, multiply the reactive forces required in the resistance of deleterious forces around us and finally to satisfy in the fullest possible manner our primary needs and to procure for us the greatest sum of pleasure and joy. ${ }^{37}$

au Saint-Simonisme, Paris, Les Editions de Minuit, 1966, and Politique, religion et science de l'homme chez Philippe Buchez (1796-1865), Paris, Editions Cujas, 1967.

${ }^{27}$ Claude-Henri Comte de Saint-Simon, Oeuvres de Saint-Simon et Enfantin, 47 vols., Paris, Dentu et Leroux, 1865-1878, vol. 39, pp. 175-176. E. M. Bailly, Parisian doctor and orator at SaintSimon's funeral, had a clear idea of recent developments in physiology. References to tissue specificity, for example, assure us of his familiarity with Bichat's work. Saint-Simon's other advisor on biomedical science, J. Bourdin, apparently was ignorant of the importance of Bichat's work. In the preface of his Cours d'études médicales (1803) he offers a simplistic and mechanical model for organic processes. Absorbed by different philosophical and scientific questions, Saint-Simon overlooked this difference which distinguished his councillors. 


\section{French medical profession's perception of its social function, 1776-1830}

Bichat's definition of life as all the forces which resist death is here applied to social life and afterwards specifically related to the cause of public health. In this sense the measure of social progress is not merely the development of science abstractly considered and unrelated to human needs. Nor is human advance confined to material gains coming from increased productivity: "The history of civilization is only the history of the life of the human species, that is to say the physiology of its different ages, as that of its institutions is only the exposition of hygienic knowledge used for the conservation and amelioration of its general health". More broadly still, "the political economy, legislation, public morals and everything which constitutes the administration of the general interests of society, are only a collection of hygienic rules whose nature must vary according to the state of civilization; and general physiology is the science which has the most data to recognize this state and describe it, since it is only the expression of the laws of every society's existence." 38 Anachronistic institutions should disappear as the society pursues its natural growth, giving birth to institutions necessary to each age of the social body. And "if the development has led to the health rules best suited to the constitutions of different epochs, why do we conserve the hygienic habits in contradiction with our physiological state? Why would we conserve administrative principles?'so

Simplifying to an extreme, Saint-Simon forecast the evolution of this industrial system in terms of the impulsion given to social life by an innate virtue just as the individual's life pursues its course without attention to the principle of growth guiding its development. The mature society, having rid itself of the trappings of childhood egoism, would witness rational principles ordering the behaviour of men and no longer submit to the imposition of arbitrary human will. Naturally enough, the most important political act, "fixing the direction towards which society should develop, would no longer belong to men invested with social functions; it would be exercised by the social body itself."40 Even if an innate and vital principle of progress developed the society from within, the social body required special groups or organs each carrying out a specific function and all animated by a moral sense which placed the common good above sectarian interest.

Among Saint-Simon's followers there were doctors, like Philippe Buchez, who considered the medical profession's social role in the light of this theory. In 1825, Buchez wrote of physiology as a science with two objects and aims: "Physiology as a science of man is called upon to supply a positive base for individual morality and as a science of the conditions of existence, to organize and survey public hygiene."41 The wage-earner's cause is social science's moral end and public hygiene, the material component of physiology, is the objective ground for action. The doctor, as social scientist, is more than a witness of need; his position requires the initiation and support of legislation to protect the worker's health. Philanthropic action, always susceptible to individual generosity and current fashion, is insufficient unless it leads to legislation which curtails health hazards.

se Ibid., p. 178.

20 Ibid., p. 190.

1 Ibid., p. 197.

¿1 Philippe-Jean-Baptiste Buchez, 'De la physiologie', Le producteur, journal philosophique de l'industrie, des sciences et des beaux-arts, 4 vols., Paris, 1825-1832, vol. 1, p. 133. 


\section{Terence D. Murphy}

This was the background for Buchez's idea of political medicine which he formulated in a series of articles appearing between 1827 and 1832. There he outlined his plan for the enlarged participation of the medical profession in social and political affairs. Essential to this intervention was the creation of institutions capable of organizing and co-ordinating the efforts of the profession. For the moment Buchez saw only a few health councils working to safeguard the population's health. Unfairly perhaps, he judged them to be "a collection of doctors without any aim, without work, only uniting and reacting on the recommendation and the whims of highplaced clients". Furthermore, "these councils have no tie between them; they are isolated bodies wherein each member is isolated. This leads to the conclusion that there is no co-ordinating agency to deal with questions of hygiene thus leaving health matters to chance." 42 To correct this situation, the nation needs the establishment of social and public hygiene on wider foundations. In a word, it is necessary to create Political Medicine. "It would take in the physiological, industrial, and moral life of people; and for its manifestation, it would have a corps of engineers and scientists who, united and centralized under a general view, would function continually and decide all questions pertaining to the health of the popular masses."43 Buchez admitted that a clear understanding of the term Political Medicine was difficult because no institution represented its point of view to government officials. The result of this negligence allowed charlatanism to exploit the people's credulity and even encouraged the cupidity of certain doctors: "nothing positively certifies their knowledge; our diplomas have no force. ... In a word there is no medical tribunal, the Academy of Medicine being ineffective in this regard. As a result the public lacks a spokesman for its interests." 44

If the public good required the establishment of such an institution, a particular interpretation of historical development predicted it. Applying Saint-Simon's historical method, Buchez argued that social needs called forth the institution which satisfied them. The development of the social organism required such institutions which would foresee future needs. In this way, the science of medicine would become the most fruitful of the sciences as it would forecast the health needs of a nation. Medicine today, continued Buchez, presents a different picture. In the hands of doctors medical science is only the representative of a multitude of ideas, whims, petty ambitions, and the speculation of individuals. As such it hinders the community's development and negates the function of any science which, Buchez recalled, is only to satisfy evident needs. The absence of any medical doctrine applicable to the population taken collectively explains this failure.

A tragic example drove home Buchez's point. Writing in 1832, when the cholera was close to Paris, he said: "This is so evident that today if the cholera approached it is certain that nobody would know what to do." 45 The negligence of public officials justified Buchez's scepticism and prompted this comment: "If there were at the head of medical science a corps, an institution of application, the government would

12 Philippe-Jean-Baptiste Buchez, 'Hygiène', J. Sci. morales politiques, 1832, 1, (9): 134.

4 Ibid., 1: 134-135.

4 Ibid., 1: 135.

es Ibid. 
have received needed advice. In the absence of such an institute and its filiates throughout France, medical science is only a science of exceptions, that is, it only concerns itself with the sick who are exceptions and accidents whereas health and its conservation for all is a general fact." 46

This social science, built after the physiological model, accepted the public good as the generating principle of human action, a principle which calls forth institutions to satisfy the needs of the collectivity. Only the inclination towards more primitive forms of social organization, fostered by self-seekers and their dependants, retarded, if only momentarily, the evolution of the group. Buchez relied on "the historical method" attributed to Saint-Simon, to arrive at these conclusions. Saint-Simon in his turn had borrowed from Condorcet, but in so doing he neglected important features of Condorcet's explanation of social development. Similarly, Buchez's own optimistic forecasts, while in accord with Condorcet's view, neglected to focus attention on a central feature of this scheme proposed by the first theoretician of social mathematics. Buchez, like Saint-Simon, sacrificed the individual's decision-making role to an innate principle of social development.

Condorcet interpreted history differently. He placed the individual in the forefront and devised a social science which tried to rationalize the process of social choice and not merely to affirm the value of certain goals. In this way, Condorcet put individual decision-making and not an ambiguous principle of growth at the centre of his social science. In so doing, he aimed at providing the political community with a rational and hence human means for the protection of civil liberties, while at the same time fostering the progressive development of its spiritual and material potential. ${ }^{47}$ Buchez's science put the emphasis elsewhere, encouraging the formation of an institution and a profession capable of carrying out a specific social function. An institute of preventive medicine, a renewed and reorganized medical professionthese would conserve the health of an emergent industrial nation. Buchez's recourse to functionalism, totally in accord with a physiological model of science, differed radically from previous justifications for the medical profession's social role.

\section{SUMMARY}

To sum up: during the Ancien Régime epidemics and endemics frequently struck France. The king's ministers, animated by humanitarian concern and the needs of state power, sponsored the Société Royale de Médecine to counter recurrent sicknesses. Concerned physicians in Paris, working in close collaboration with medical practitioners, set up a network of communication to link local communities to an administrative and scientific centre. During the French Revolution the Société and the medical profession came under attack from liberals who proclaimed the end of institutional and professional privileges. But the country soon felt the absence of a well-trained group to care for the population and especially to assist those wounded in the Revolution's wars. To meet this need the state reorganized medical practitioners

\footnotetext{
46 Ibid., 1: 153.

47 My discussion of Saint-Simon's relation to Condorcet follows that of Keith M. Baker, Condorcet: from natural philosophy to social mathematics, Chicago, University of Chicago Press, 1975, pp. 375377.
} 


\section{Terence D. Murphy}

and supervised their training. State control, however, did not suit the profession's leaders who soon asserted their right to independence from political and military authorities. In the wake of these disputes, physicians debated the profession's social function and enquired into the formal ties between doctors and the state authorities. Some, like Bichat, argued for medicine's scientific vocation and concentrated on advancing internal medicine. Others, like Fodéré, Villermé, and Buchez, advocated that medical practice respond directly to social needs, particularly those generated by early industrialism. Practically speaking, they shared a desire for an efficacious public health system. They differed, however, on a number of crucial issues, differences which not only reveal the political implications of medical practice but also demonstrate the importance of its cultural context. 